\title{
Institutional Features of National Personnel Policy and Social and Labour Relations in Higher Education Establishments
}

\author{
Pavel Vladimirovich Simonin \\ Alexander Nikolaevich Ananev \\ Veronika Andreevna Danilova \\ Tatiana Vyacheslavovna Bogacheva \\ Tatiana Nikolaevna Lustina
}

Russian State University of Tourism and Service, Cherkizovo village, Moscow region, Russian Federation

Email: simoninp-v@mail.ru

\section{Doi:10.5901/mjss.2015.v6n3s3p283}

\section{Abstract}

Social and labour relations in higher education institutions are in a state of transformation on institutional, legislative, rulemaking levels. To improve the quality of national personnel policy in respect of higher education institutions it is necessary to enhance the process of its realization on institutional level by expanding the spectrum of educational services with account of their quality, adapting new institutional form of social and labour relations - the effective contract in higher education institutions, developing social safety policy and providing fair salary for higher-education teaching personnel with due consideration of key performance indicators.

Keywords: personnel policy of education institutions, social partnership, effective contract, institutional framework stagnation, collective bargaining contract, labour unions.

\section{Introduction}

\subsection{Introduce the Problem}

For years of market reforms the view of social and labor relations has crucially changed. The actuality of building goaloriented national personnel policy for development of the system of social and labour relations is stipulated with the fact that today existence of weakly functioning institutes does not provide social security and acceptable level of living of academic and teaching staff in the capacity of "middle class", while the institutional standards are often of declarative character that provides no availability of equal right negotiations. For effective realization of personnel policy it is necessary to identify social needs of pedagogic staff and conduct analysis of social and labour relations in the area of available guarantees and compensations, job conditions, social security programs, participation in negotiation processes, etc. The present information should be the basis for development of education institutions' personnel policy and serve as a milestone for regulation of social and labour relations, functioning of social partnership system on the basis of principles of equal rights and equivalence of parties.

\subsection{Importance of the Problem}

In the course of conducting dynamic transformations in higher education institutions it has become evident that existing institutes are not capable of providing effective social and labour relations formation to enough extent without presence of goal-oriented national personnel policy.

In the period of national academic and teaching staff labour market development, under the conditions defining stagnation of institution structure and dynamic institutional traps there are methodical problems linked to the absence of studies of institutional foundation of "social partnership in education institution" category, as well as to violation of personnel structure reproduction equilibrium, inefficient mechanisms providing fair salary, social levers predetermining 
effective communication with labour unions.

In such a way the identification of features of social and labour relations in the process of realization of national personnel policy in higher education institutions will promote protection of professional interests of teaching staff concerning salary, formation of professional competitiveness, creation of stable working positions system and safety conditions for labour use.

\subsection{Relevant Scholarship}

The analysis of results of researches of leading scientists and scientific literature witness insufficient theoretical development of problem of institutional labour relations on the basis of national personnel policy.

However, the special attention should be paid to scientific and research works of such Russian and foreign scientists with a focus on building effective social and labour relations in the context of institutional principles realized by education institutions are: Armstrong M. (Armstrong M., 2010), Gibalo N. (Gibalo N., 2002), Putman R. (Putman R., 1993, 2000), Hopkins R. (Hopkins R., 1985), etc.

Besides, the special attention was paid to theoretical and methodological backgrounds of social and labour relations, social changes and personnel policy: Gompers S. (Gompers S., 1912), Simonin P. (Simonin P., 2014), Morozova L. (Morozova et al., 2014), Bogacheva T. (Bogacheva et al., 2014), Oksinoid K. (Oksinoid K., 1999), Khavanova (Khavanova, 2007), Mikhalkina E. (Mikhalkina E., 2013), Crouch C. (Crouch C., 1999), Schneider F. (Schneider F., 1997), Sugden R. (Sugden R., 1989), etc.

At the same time, to bigger degree scientists have researched the theoretical and methodological backgrounds for formation of institutes, separate aspects for personnel policy formation and essential content of these categories. The mechanisms for realization of social and labour relations with account of institutional aspects were also researched. However, such matters as improvement of quality of realization of national personnel policy in higher education institutions, including clearly formulated goals of social and labour nature, methodology for their realization and also principle stages of personnel policy, development priority directions, recommendations on formation of system of key performance indicators, mechanism for participation of scientific and pedagogic staff in collective negotiations with account of new reform of education system have no relevant scientific reflection and require further conceptual development in respect to higher education institutions.

\subsection{State Hypotheses and Their Correspondence to Research Design}

Taking into account scientific crudity of the present problematics, the main goal of research is the development of principle stages of national personnel policy in higher education institutions and social and labour relations (SLR) with consideration of new institutional forms on the basis of research of theoretical and methodological backgrounds of personnel policy and SLP, methodic and scientific and practical recommendations on realization in higher education institutions.

\section{Method}

To reach the stated goals the general scientific and special methods were used: comparative-historical, statistical analysis, sociological surveys, and expert analytic method.

\subsection{Comparative analysis method}

In the paper there is parallel research, comparison of different concepts on the basis of comparative-historical analysis necessary for formation of new institutional forms of social and labour relations in higher education institutions. By the way of comparison of performance indicators management we have proven the role of effective contract, in which the key performance indicators (KPI) developed by higher education institutions should be considered, identified the role of a state as the participant of one of the parties of social partnership and market regulator, due to which higher education institutions can define the personnel policy for employees with account of current conjuncture of educational services market. 


\subsection{Statistical analysis method}

In the present research we have used selective statistical monitoring for identifying trends and regularities of state of: social and labour relations, availability of concluded collective contracts, applicable labour legislation, potential risks of mass labour strikes, social and juridical security of teaching and academic staff, satisfaction of labour and wage level, etc. On the basis of obtained data about the state of sphere of teaching personnel labour the suggestions concerning formation of principle stages of national personnel policy were formulated.

\subsection{Social survey method}

With help of interview method we have performed the gathering of primary information about the state of social and labour relations in higher education institutions, as well as data of subjective nature about opinions, appraisals, directives, motivation and preferences of respondents, attitude towards conducting personnel policy. On the basis of gathering of obtained information the matrix of personnel policy and correspondent estimated figures were designed. The present matrix form has provided studying the character of SLR depending on their position in the matrix and connecting different sources of information about social and labour processes on the basis of emphasis of national personnel policy stages realized in higher education institutions.

\subsection{Analytical method}

By means of expert analytic method the main disadvantages restraining development of institutional system of social and labour relations were identified and the estimation of analysis results was conducted. On the basis of expert survey the principle stages of national personnel policy with appraisal of their preferences were developed, recommendation on formation of effective institutional system of social and labour relations in higher education institutions were given.

\section{Results}

The improvement of mechanism of national personnel policy in respect of education institutions is being one of priority directions of state's activity on coordination of affairs for the purpose of increase of stability of labour potential of society. The structural alteration of society values, its ideology, creation of market infrastructure and economy involve changes in the character of public relations and their social and economic regulation. The problem of reaching equilibrium in the process of formation of national personnel policy is being extremely relevant.

The state of the sphere of social and labour relations and its institutes depends on key factors of national economy development. As Putman R. rightly underlines: "Without standards for mutual aid, without networks of associativity and civil community the amoral domesticity, clientalism, lawlessness, inefficient authority and economic stagnation are to be more probable outcome than actual democratization and economy development" (Putman R., 1993). At the same time he considers that "transformation of institutes can change political practice and traditions" (Putman R., 2000). That is why the emerging of new institutional models and forms will define: a) transformation of values; b) mechanism for change of system of standards and rules in higher education institutions; c) development of new personnel strategies, etc. It is obvious that government reforms in the system of higher education can initiate internal change incentives, adoption of solutions concerning formation of personnel policy in particular education institution with due consideration of existing rules, standards and institutes.

Hopkins P. notes that "it is quite difficult adequately to response the needs of pedagogues, for there is no precise understanding of who are they, where do they work and their labour's content (Hopkins P., 1985). The point at issue is that due to the clarification of factual state of sphere of social and labour relations it will be possible to develop stable procedures of personnel policy in respect of higher education institutions. As a matter of fact, the social and labour relations cannot be analyzed without considering of needs of those working in an education institution and legal framework, applicable legal and regulatory acts, which make definite impact in formation and development of the sphere of social and labour relations in higher education institutions.

As Morozova L. fairly states, today the improvement of the sphere of social and labour relations continues, democratic transformations aimed at coordination of national and personnel policy of specific education institutions are actively held. At the same time there is a priority task of development of social and labour relations on the basis of mutual coordination of interests of state, wage worker and employers (Morozova L., 2014).

However, studying the ways of social and economical relations and social responsibility the Nobel laureate Alle M. 
has stated that "economy of markets is being an integral part of institutional frameworks, in which it works". This is true for definite institutional structure forms "support structure" of social and economical relations. The institutional building promotes prevention of transformation of liberalization into anarchy and social irresponsibility (Gibalo et al., 2014).

In such a way, of principal significance are labour relations with definite institutional structure, which describe interrelations between employer and employee on work position. They can be just as of official nature, for example - the contracts concerning hired labour, so of informal nature - in the form of psychological contract, in which there are definite suppositions and expectations concerning the matters of what employer and managers shall offer and what they agree to give. The labour relations can bear individual character (the individual contracts and expectations) or collective (the contracts between headship and labour unions, associations of workers or members of joint consulting bodies, such as works councils) (Armstrong M., 2014). It is obvious that it appears in so-called growth of formal and informal institutions that regulate social and labour relations.

At the same time, an eminent representative of school of social and labour relations Oksinoid K. distinguishes the feature that makes the difference between social and labour relations and other types of social and labour issues (the social and labour contracts, actions and interactions) and that implies the interactions used for building of the present relations are based on correspondent standards, submit to them and are regulated by them. In this connection we should notice that we talk not about all the interrelations, but only about those having place with regard to labour activity, its social and cultural and subjective meanings, goals, content and results (Oksinoid K., 1999).

On the assumption of all above-said matters we can make two conclusions: 1) social and labour relations (SLR) in higher education institutions form subjectively existing interconnections and interrelations between individuums and their groups on the basis of applicable standards that are stipulated with labour activity and aimed at regulation of quality of working life and harmonization of relations on the basis of social dialogue. As a result the analysis of social and labour relations in the frameworks of institutional structures in the context of national personnel policy is being more large-scaled and complicated process; 2) social and labour and psychological aspects of named interconnections, as well as legal relations, demonstrate the link between separate subjects on institutional, legislative and rule-making level.

This appears in the diversity of subjects of social and labour relations and correspondent institutes, which create a platform for regulation of occupation, organization and productivity of labour, system of higher education institutions' personnel remuneration with account of market principles. The involvement of higher education into market relations implies, primarily, the quality of rendered educational services and also implementation of effective management elements into higher education institutions' science and teaching process that meanwhile remains in the areas of vain wishes. Russia needs modern educational model that will be adequate to the realms of life of society, in which the leading role is taken by the staff of education institutions that represent the present services.

The problems of regulation of labour interrelations between workers and employers are solved in the frameworks of the system of social partnership designed to promote the coordination of interests of subjects of social and labour relations. In the sphere of government regulation there are matters of definition of standards and rules for conducting of collective negotiations, order of labour disputes settlement, right and responsibility of participants, recommendations on development and coordination of collective contracts and agreements.

On the federal level there is Russian three-party commission on regulation of social and labour relations. The similar commissions are created and work in branches and regions. That is why the priority task is the realization of national personnel policy in respect of higher education institutions with account of representative bodies.

All these measures are designed to provide the right of hired worker for work under conditions that would be safe for his health, fair compensation of his physical, emotional and intellectual expenses linked to the performance of work, professional growth and development, as well as the realization of his labour interests (Kibanov et al., 2009).

The works of Crouch C. make significant contribution in research of brand new model of social and labour relations in higher education institutions from the perspective of government. The logical essence of the present labour relations and social guarantees is defined by the following matter: "The struggle of population for confidence in the future in such a case takes the form of protective role of social state (it is more typical for the Northern Europe), while different levels of guarantee are partly provided by different form of labour contract and closely related labour rights. To some degree these area become the battlefield linked to distribution and, subsequently, to political conflicts, since different demographical and professional categories reach different levels of social rights" (Crouch C., 1999). This very approach is reflected in trade-off theory. The central factor here is the idea of reaching agreements in social and labour sphere on the basis of mutual concessions. This, in particular, means that parties participating in collective discussion of problems should to some degree abate, on the basis of which it becomes possible to choose the progressive variant of relations without impairment of social rights.

The core of guaranteed social and labour relations in the concept of Schneider F. is the model of "labour contract, 
in which some workers have conserving stake and guaranteed work place, while other are more assailable, as they, for example, have temporary contracts, non-guaranteed occupation term, etc. (Schneider F., 1997). In this case the present concept can clue employers in on change social and labour relations' quality. In fact many higher education institutions practice conclusion of labour contracts with teaching staff for the period of one year that devaluates their social occupation guarantees. That is why the main methodological grounds, upon which the sphere of social and labour relations in higher education institutions rests, should be: firstly, the presence of effectively acting "labour unions that strive to facilitate labour and make life better" (Gompers, 1912); secondly, the national personnel policy oriented at equilibrium of interests, not at vertically command guidance in respect of higher education institutions, should be developed; thirdly, the social partnership as necessary element of institutional system should be provided; fourthly, there should be social fairness on the basis of applicable labour legislation and prolongation of labour contracts.

In search of scientific way that could provide development of institute for security of working rights and social partnership on the basis of factually acting labour unions next we will refer to analysis of the present sphere: a) starting from 1997 in the Russian Federation no less than 221 regional agreements have been registered. The practice of making territorial agreements on the municipal level is increased, while in 26 constituents of the Russian Federation such agreements are available in all the municipal entities. Another positive factor is the increase of specific weight of education institutions participating in collective negotiations; in $88 \%$ of education institutions the collective contracts were applicable. At the same time, $76 \%$ of higher education institutions had labour union organizations and in $89 \%$ of them the collective contracts were concluded; b) "the distinctive feature of artificially created relations of social partnership is the disparity of its parties that lies in obvious dominance of government in case of labour unions' frailty and absence of responsible embassy of employers; c) the data of labour union organizations' monitoring show that almost half of rankand-file members consider the labour unions on a nationwide scale can't protect the workers' rights; $64 \%$ of respondents suppose that a labour union is not capable of influencing the wage increase. In such consequences the rank-and-file members demonstrate personal passivity, and $60 \%$ of respondents had not participated in preparation of collective contract" (Karelina, 2005).

The analysis shows (table 1) that the bulk of respondents $(66,7 \%)$ had not participated in development of collective contracts and agreements and only 11,1\% was partially involved in the process. According to information obtained in the course of survey it becomes clear that more than half of personnel of higher education institutions attach no importance to collective discussion of such matters as: salaries, extra charges, premiums, etc. All these witness the low role of collective contracts in the life of teaching staff.

Table 1 - Distribution of respondents' answers concerning social and labour relations in higher educational institutions ${ }^{1}$ (in \% from number of respondents)

\begin{tabular}{lc}
\hline Answers' variants & $\%$ \\
\hline Personal participation in framing of collective bargaining contract & 33,3 \\
\hline Compliance with Labour Code of the Russian Federation & 88,8 \\
\hline Timeliness of salary payment & 77,7 \\
\hline Participation in collective negotiations in partnership with labour union organization & 22,2 \\
\hline Guarantees and compensations in case of termination of labour contract & 44,4 \\
\hline Fear of dismissal in case of labour strike actions & 55,5 \\
\hline Concern of duration for conclusion of labour contract (for 1 academic year) & 88,8 \\
\hline Regularity of settling upon work position & 66,6 \\
\hline Absence of compensation for extra teaching load & 77,7 \\
\hline Level of salary satisfaction & 11,3 \\
\hline Direct work satisfaction & 22,2 \\
\hline
\end{tabular}

The results of researches provide describing actually existing problem of deformation of institute of social partnership and salary in higher education establishments.

Thus, for example, in 2014 the level of ones satisfied with their salary made only $11,3 \%$ of total number of respondents. Such prerequisites to deformation of institution of salary and low labour satisfaction $(22,2 \%)$ are linked to greater degree to "underpayment of workers of budget sector in relation to comparable (with similar observed characteristics) workers of non-budget sector making about 30\%" (Sharunina, 2012).

1 The survey was conducted by the authors in 2014 by the example of one of state higher education institutions of the Russian Federation. 
At the same time the liquidation of unified wage tariff system and extension of higher education institutions' independence in reward of teaching staff have lead, according to the data of Ministry of Education, to 1,7 times increase of their average wage (from 19,1 to 21,7 thous. rbs.) in 2008-2012, and for other workers - to 2,2 times increase (from 10,8 to 23 thous. rbs).

By 2018 the average wage of teaching staff using modern technologies, carrying out the scientific work and teaching in graduate and postgraduate schools is to exceed the regional wage two times due to three sources - the budget, the internal higher education institutions' resources (including reduction of the share of payment of office and management personnel from 50 to $40 \%$ ) and the increase of payment for contract education up to the budget level, i.e. 1,5-2 times (Blyakhman, 2014).

Insufficient qualification of teaching staff. In 1993-2012 the number of students had increased almost three times, and the teaching staff $-56 \%$ (from 220 to 342 thous.). As a result, the number of students per one teacher (15-20) in Russia is 2,7 times bigger than in the USA. In 1980-2010, according to the data of Inozemtsev V.L., the number of ones taken graduate degrees had increased 5,6 times, however they do not stay for working in higher education institutions, the average wage in which by 2012 (21,7 thous. rbs.) was lower than mid-Russian wage and in 56 more constituents of the Russian Federation - lower than regional one. What is for education as a whole, the wage made 15 thous. rbs. - i.e. 2/3 from average wage in economy.

In addition, it is necessary to mention another one specific feature. Talking about work of labour union organization, its members, as well as its head, as a rule, very seldom refer to cooperation with employer, attempts to assert fair salary and protect labour rights of workers. They talk about cultural-mass or distributive work: organization of holidays, sport affairs, children's competition, etc. Even more seldom they talk about the possibility of workers' rest organization. And here we can conclude that labour unions are not considered by workers to be the power that can change some aspects of labour relations to their advantage (Yadov, 2013).

That is why in methodological terms the concept of efficiency of legal instruments for security of labour rights more and more displace to the idea of solidarity. We should note that 'the legal framework for labour unions' activity shrinks, government reduces the set of legal instruments for security of workers' labour rights. As a result the labour unions have to return to the idea of solidarity" (Borisova et al.). In this context the labour unions of higher education institutions in particular, the labour unions acting on the principles of solidarity will promote flexible adaptation to the changes taking place in the system of professional education. In such a connection there is a possibility of studying role of national personnel policy in building of social and labour relations in higher education institutions.

However, from the perspective of institutialism the idea of solidarity also remains insufficient. In this context it is the institution of national personnel policy that should become an efficient factor of mobilization and concentration of efforts of government and public institutes aimed at solution of tasks for stable development and effective use of personnel potential of the country, completing and professional improvement of higher education institutions' staff. The central component of the policy is the strategy of federal bodies on formation, development and rational use of labour resources of the Russian Federation, mobilization and professional use of personnel potential.

In our opinion, the definition of the category of "personnel policy of government in respect of educational institutions" of higher professional education in the discourse of institutional economy should be understood as formation of strategy for personnel work, setting of goals and tasks on the basis of scientific principles of selection, arrangement and development of teaching staff and other employees, improvement of forms and methods of work on formation of efficient social and labour relations.

It is obvious today that content and characteristics of the present category is justified. For the day the national personnel policy in respect of higher education institutions is more often aimed at optimization of number of teaching staff that predetermines significant release. Recently more and more attention is paid to the fact that factual number of teachers in higher education institutions makes $30 \%$ excess over standard indicators. It is also obvious that the new course of government brings other understanding of national personnel policy in respect of higher education institutions. Thus, for example, at average for 2009-2013 the reduction of teaching staff of state higher education institutions was increasing 13625 people or 4,18\%. At the same time the number of students as per 10000 people of population has notably decreased. The scale of such decrease is witnessed by the data, in accordance with which in the beginning of 2009 the present indicator made 430 people, while in 2013 - 331 people that is $23 \%$ less. The extremely negative fact is that in case of continuation of such a trend there will be unavoidable retrenchment of higher education institutions' personnel. Apparently the present circumstance is caused by conducted governmental reform of the system of higher professional education that step by step reflects in transformation of personnel policy of higher education institutions of the country.

Sugden A. states that on the way of transformation of labour relations on the basis of rigid mechanism of national 
personnel policy in higher education institutions there are major difficulties. He writes: "Due to the fact that standards are distributed by analogy one should not necessarily expect for them to turn out to be the optimal solution of particular problems" (Sugden A., 1989). Thus, it becomes clear that there are cardinal changes of educational system, its regulatory content and quality of organizational processes, which cannot lead to equilibrium of interests of each of parties of social and labour relations in a moment.

So, no matter how the improvement of national personnel policy and legislative in the sphere of education will be performed - there is a question about "human and intellectual capital" of higher education institutions. Thus, for instance, today there are intense attempts to down grade the role of teaching staff in provision of main educative programs' realization on various levels of higher professional education, tendencies towards cancellation of guarantees that provide "equitable conditions for work". The educational reform can hardly be considered effective in case, if the interests of teaching staff together with their motivational component were hurt. Firstly, there is significant increase of number of violations in the "proportion of teaching work and other pedagogic activity within a workweek or an academic year." Secondly, the problems of interaction in realization of personnel policy of education institutions under conditions of new federal law have become much more complicated.

However, there are elements of new educational system that influence the formation of national personnel policy and remain much more transparent and clear. They are: 1) academic rights and freedoms: the freedom of educational activity, expression of individual opinion, protection against interference in professional area of activity, choice of forms and teaching method, etc; 2) structure and content of work time, including: teaching, educational work, individual work with pupils, scientific, creative and research work and other pedagogic activities; 3) obligation of using approved work programs when realizing general educational program; 4) absence of obligatory certification for teaching staff for the purpose of defining of qualification grade; 5) target costs for provision of average salary level for pedagogic workers in accordance with decisions of state authority bodies, etc. (Simonin, 2014).

As quite developmental we can consider the experience of social partnership in leading education institutions of the Russian Federation, in which the institute of social partnership is based upon clearly designated mechanism of solvatation of the parties: government, hired workers and their representatives, employers. Beyond any doubt, there is a necessity of government's participation in the tri-partisanship system. However such participation will be reasonable only from the perspective of explicitly defining processes of mass labour strikes, acute problems, control and guarantees on compliance with basic standards, level and quality of living, conditions for labor remuneration, social protection, etc. That is why labour unions and employers in increasing frequency interact between each other directly and, as a rule, set a goal of avoiding involvement of authority representatives into social and labour relations.

Moreover, the limiting factors of development of social partnership process in the sphere of education are:

- slow formation of representative employers' bodies in the branch (thus, the Federal law "Of associations of employers" adopted in 2002 does not consolidate the specificity of employer's status in budget sphere, despite the fact the Central Committee of Labour union had continually introduced its remarks and suggestions on consolidation of the specificity in law);

- problems of government's liability recovery in the sphere of education that remain unsolved to the full extent, separation of jurisdictions and liability of government authority bodies in constituents of the Russian Federation and local self-governing bodies in provision of stable financing of branch's institutions;

- extremely low financial provision of collective contracts and agreements of all the levels;

- absence of systematic approach to formation of personnel policy in the branch;

- underdevelopment of pedagogic labour market, absence of interconnection between planning of professional training, retraining and advanced training of pedagogic personnel and requirements of labour market;

- insufficient level of informational exchange and coordination of work in terms of social partnership between Ministry of education and science of the Russian Federation and the Central Committee of Labour union, as well as between education management bodies and territorial labour union bodies in the constituent of the Russian Federation, etc. (Avdeenko, 2006).

In the entire cases one should take into account the interconnection of different types of educational resources and separate aspects of social partnership. In the meantime it is necessary to note that successful development of social and labour relations in higher education institutions with due consideration of world economy globalization has a direct impact on national labour markets and indirect impact (through the role of institutional regulators) - on the direction and rates of social partnership in the sphere of social and labour relations (Bogacheva T.V. et al., 2014).

Thus, the increase of labour intensity can be linked to additional load of teaching staff in the area of keeping electronic educational documentation with account of new technologies. As a result of teaching process automation there can be additional expenses of work time, which should be normalized and introduced in total load of teachers (Simonin, 
2014). The specified thesis witnesses the dominant role of development of efficient collective agreements that would support the necessary correlations in remuneration of labour in the framework of social partnership.

When realizing the outranking approach to solution of social and labour problems it is accepted to distinguish the following stages (Khavanova, 2007):

- development stage, at which one or several indexes for pair-wise comparison of alternatives are made;

- research stage, at which the made indexes are used for ranging of specified set of alternatives.

The indexes for pair-wise comparison of alternatives are made on the principles of consents and dissents. In accordance with the principles, the alternative $\mathrm{A}_{\mathrm{j}}$, if:

- sufficient majority of criteria confirms the statement (principle of consent);

- objections on the rest of criteria are being not very strong (principle of minor dissent).

The present approach is based on construction of binary relations. The binary relation $\mathrm{R}$ defined at finite set of $\mathrm{A}$ alternatives is called (when $\forall A i, A j \in A$ ):

- complete, if $A_{i} R A_{j}$ or $A_{j} R A_{i}$;

- transitive, if $A_{i} R A_{j}, A_{i} R A_{k} \Rightarrow A_{i} R A_{k}$;

- full order, if it is being complete or transitive;

- partial order, if it is being transitive, but not complete.

Let $x_{i}^{k}, x_{j}^{k}$ be the estimation of alternatives $A_{i}, A_{j}$ by $k$ - criterion. The relation of preference of a person, who makes a decision, when comparing alternatives by one criterion is being full order.

The pseudocriterion is the trio $\left(x_{j}^{k}, q, p\right)$ of functions that represent the preferences of a person, who makes a decision, and are defined in a way that concludes in:

- $q\left(x_{i}^{k}\right)+x_{i}^{k}>x_{j}^{k}$, if by $k$-criterion $A_{i}$ possesses a strong preference in comparison with $A_{j} ;$

- $x_{i}^{k}+q\left(x_{i}^{k}\right) \geq x_{j}^{k}>x_{i}^{k}+p\left(x_{i}^{k}\right)$, if by $k$-criterion $A_{i}$ possesses a weak preference in comparison with $A_{j}$.

The $A_{i}$ and $A_{j}$ alternatives are in the relation of indifference by $k$-criterion $\left(x_{i}^{k} \approx x_{j}\right)$, if strong or weak preference of one of the alternatives is not identified.

The indexes of consent and dissent are made in the following way. Each of $\mathrm{N}$ criteria is placed in correspondence with $w$ being a whole number that characterizes the importance of a criterion and is considered the number of experts' votes cast for the importance of the present criterion.

Thus, there is a hypothesis of superiority of $A_{i}$ alternative over $A_{j}$ alternative. The I set that consists of $\mathrm{N}$ criteria is subdivided into three subsets:

- $I^{+}$- the subset of criteria, according to which $A_{i}$ is more preferential than $A_{i}$;

- $\quad \mathrm{I}=$ - the subset of criteria, according to which $A_{i}$ is equal to $A_{i}$;

- $\quad$ - - the subset of criteria, according to which $A_{j}$ is more preferential than $A_{i}$.

Next, the index concordance index with the theory of superiority of $A_{i}$ over $A_{j}$ is formed. The consent index is calculated on the basis of criteria weight. The index is defined as relation of $\mathrm{I}^{+}$and $\mathrm{I}^{=}$subsets' criteria weight to total sum of weights.

The consent index possesses the following properties:

1) $0 \leq C_{A i A} \leq 1$;

2) $C_{\text {AiAj }}=1$, if I- subset is empty;

3) $C_{\text {AiAj }}$ preserves value in case of substitution of one criterion with several criteria possessing the same total weight.

The dissent index possesses the following properties:

1) $0 \leq d_{A i A} \leq 1$;

2) daiAj preserves value in case of introducing of more detailed scale by the i-st criterion with the same length.

The introduced indexes are used when constructing the matrix of consent and dissent indexes for specified alternatives.

The binary relation of superiority is assigned to the levels of consent and dissent. So, if $C_{A i A} \leq \mu_{1}$ and $d_{A i A} \leq \beta_{1}$, where $\mu_{1}, \beta_{1}-$ are the specified levels of consent and dissent, the $A$ alternative is considered superior to $B$ alternative.

If the comparison of the alternatives under the present conditions failed, they are declared to be incomparable. From the methodological point of view, introducing of incomparability concept is being very important. If the estimation of alternatives is contradictory to significant degree, such contradictions cannot be compensated that means such alternatives cannot be compared.

If we have the specified levels in the set of alternatives, we should distinguish the core of non- dominated elements, which are either in the relation of incomparability, or in the relation of equivalence. In case of change of the 
levels in the present core we should distinguish the smaller core, etc. Thus, there is a possibility of suggestion to a person, who makes decisions, of the entire series of probable solutions of a problem in the form of different cores. As a result we can get one best alternative. The values of consent and dissent indexes characterize the degree of requirements' rigidity, at which the ultimate conclusion is made.

In such a way, the principle stages of methodological estimations that provide formulation of priorities of social partnership and personnel policy are the following:

\section{Indexes Development Stage}

1. On the basis of specified estimations of two alternatives the values of consent and dissent indexes are calculated. The indexes define consent or dissent in regard of the hypothesis of superiority of Ai alternative over $A_{j}$ alternative.

2. The levels of consent and dissent compared to calculated indexes for each pair of alternatives are specified. If consent index is higher and dissent index is lower than the specified level, this means one of the alternatives possesses superiority over another one. Otherwise the alternatives are incomparable.

\section{Alternatives' Set Research Stage}

1. The dominated alternatives are removed from the set of alternatives. The rest of alternatives form the first core. The alternatives making the core can be either equivalent, or incomparable.

2. Introducing of more weak values of consent and dissent levels, wherein the cores with smaller number of alternatives are distinguished. The last core gets the best alternatives. The sequence of cores defines ranking of alternatives by quality.

The principle stages of the present methodological estimations can be used for analysis of development of personnel potential of higher education institutions that apply "effective contract", which is being a new institutional form of social and labour relations (Mikhalkina, 2013).

We should also note the effective contract is to be understood as a labour contract with worker, in which his job duties, wage conditions, indicators and criteria for estimation of efficiency of activity for setting incentive payments depending on the labour results and quality of state (municipal) services, as well as measures for social support, are specified.

At the present time, despite positive dynamic of creation of new institutional model of social and labour relations, the key (qualitative and quantitative) indicators of teaching staff performance estimation are not considered yet. Under the influence of high and diversified dynamism of changes in educational system the number of questions emerges:

- Will the qualitative and quantitative indicators be considered in effective contract?

- In what way they will be linked to the quality of rendering of educational services?

- What interrelation will be between education institution's policy and national personnel policy?

As a result of adoption of number of federal laws (FL No. 273 "Of education in the Russian Federation") and recommendations in respect of using effective contract, there is a necessity of emerging the role of government in establishing social dialogue between employers and hired workers, overcoming controversies between them, decrease of strain in society (Morozova et al., 2013). All these turn out to be possible in the applicable system of teaching staff management only on the basis of provision of decent work. When designing a new institutional model of social and labour it is necessary to take into account the role of government's active participation in social dialogue, stimulation of development of social responsibility as favourable field for increase of social guarantees for hired workers and subsequent growth of effectiveness and competitiveness, i.a. - of education institutions (Khavanova, 2007).

The inexpediency of applying of institutional models without their subsequent assimilation is quite substantiated. As far as in their general form they should be linked to the process of defining and consolidating of social standards, rules, statuses and roles and reduced to the system, which will work for satisfaction of social needs and needs of social subjects that can be both - separate persons and groups (Telicheva, 2005). In accordance with above-listed text, the institutionalization of social and labour relations should provide availability of entire spectrum of public relations stipulated with force of labour right and social responsibility of education institutions, availability of adaptation mechanisms providing effective import of institutes as applied to social and labour sphere. There are no doubts that the present tendencies will reflect in the process of national self-identification and collective activity. Otherwise it would promote formation of institutional structure's stagnation, i.e. - the impossibility of full and fast adaptation of this or that model due to sacramental mentality and steady economic habits of society. 
At the same time the presence of dynamic institutional traps in the Russian Federation will not provide the sufficient realization of the system of national personnel policy in reproduction of scientific and pedagogic staff, formation of institute of social partnership and salary without development of its distinct stages and analysis methodology.

In our mind, to identify the state of this or that stage of realization of national personnel policy in higher education institutions one should use the matrix of analysis of national personnel policy that consists of several successive steps (table 1).

Table 1 - The matrix of analysis of national personnel policy in higher educational institutions

\begin{tabular}{|c|c|c|}
\hline Principal stages & Result of a stage & Possible content \\
\hline \multirow[t]{4}{*}{$\begin{array}{l}\text { Stage 1. Initiation of personnel policy } \\
\text { Definition of policy goals and development priorities }\end{array}$} & Detection of problem areas & $\begin{array}{l}\text { - Formation of representative bodies; } \\
\text { - conclusion of separate collective contracts; } \\
\text { - accounting of disagreements and collective disputes; } \\
\text { - mediation in negotiation process; } \\
\text { - policy of selection, recruitment and optimization of higher } \\
\text { education institutions personnel number; } \\
\text { - payment, employment terms, etc. }\end{array}$ \\
\hline & Definition of key tasks & $\begin{array}{l}\text { - formation of effective labour collectives; } \\
\text { - creation of conditions for development of human and scientific } \\
\text { and innovation potential; }\end{array}$ \\
\hline & $\begin{array}{l}\text { Development of strategic } \\
\text { goals }\end{array}$ & $\begin{array}{l}\text { - formulation of strategic goals for the nearest } 3 \text { - } 5 \text { years with } \\
\text { subsequent step-by-step implementation. }\end{array}$ \\
\hline & $\begin{array}{l}\text { Formulation of directions for } \\
\text { the development }\end{array}$ & $\begin{array}{l}\text { - scientific and innovation and personnel potential on the basis } \\
\text { of young people attraction; } \\
\text { - investments in scientific and innovation and human capital. }\end{array}$ \\
\hline $\begin{array}{l}\text { Stage 2. Personnel policy formation } \\
\text { Development of concept with account of parties' } \\
\text { interest and its legitimation }\end{array}$ & \multicolumn{2}{|c|}{$\begin{array}{l}\text { Development of conceptual provisions in the process of formation, distribution and use of } \\
\text { personnel potential of higher education institutions }\end{array}$} \\
\hline $\begin{array}{l}\text { Stage 3. Personnel policy realization } \\
\text { Performance and monitoring by authorized federal } \\
\text { bodies of executive authority }\end{array}$ & \multicolumn{2}{|c|}{$\begin{array}{l}\text { Actions of executive authority bodies concerning realization and supervision for social and labour } \\
\text { processes realization }\end{array}$} \\
\hline $\begin{array}{l}\text { Stage 4. Assessment of personnel policy } \\
\text { Efficiency assessment }\end{array}$ & $\begin{array}{l}\text { Appraisal of results in the } \\
\text { process of realization of } \\
\text { personnel policy and its } \\
\text { efficiency }\end{array}$ & $\begin{array}{ll}\text { - } & \text { number of cases of labour legislation violations; } \\
\text { - } & \text { number of cases of rendering legal assistance and consulting } \\
\text { in commission for labour disputes; } \\
\text { - } & \text { coverage of higher education institutions by collective } \\
& \text { contracts, in \% from total amount of higher education } \\
& \text { institutions; } \\
\text { - } & \text { average nominal and actual wage of teaching personnel by } \\
\text { - categories; } \\
\text { - number of active participants in activity of labour unions in } \\
\text { negotiation processes. }\end{array}$ \\
\hline
\end{tabular}

In accordance with suggested personnel policy, there should be new ideology of work with staff composition of higher education institutions or separate professional groups of employable population. This factually implies the reconstruction of existing professional staff with account of character of its labour activity.

As practice shows, when forming national personnel policy it is necessary to take into consideration the need of institutions in personnel of correspondent qualification. That is why the creation of condition for effective use of labour reserve should mean agglomeration of national personnel policy and bodies of state authority. In other words, the measures developed by state bodies should be aimed at qualitative and quantitative provision of different economy sectors with staff of suitable qualification when rendering educational services.

To improve the quality of realization of national personnel policy it will be necessary to:

- hasten a process of formation and realization of effective personnel policy;

- expand the spectrum of educational services with account of their quality;

- adapt citizens in the process of their professional training and retraining;

- form the policy of social security and organization of fair wage with account of key performance indicators, etc.

Thus, the national personnel policy should imply the development of correspondent goals in respect of education institutions' staff referred to affairs, stages, results, defining of performers' composition, necessary resources, and its regulatory and methodic and motivational provision. 


\section{References}

Avdeenko, M.V., Aleshina, T.M., Ponkratova, V.N. (2006). Social partnership in the sphere of education. Textbook. Moscow, Moscow State Regional University Press, p. 9.

Armstrong, M. (2010). Human resource management practice. 10th is. / Translated from English ed. by Mordovina S.K. St. Petersburg: Piter, p. 219.

Blyakhman, S. (2014). Economics of education No. 3, pp. 65-67.

Bogacheva, T.V., Lustina, T.N., Panova, A.G. (2014). Current trends of social and labour relations and corporate social responsibility development (job system development and economic growth in regions) // Academic and research journal "Normirovanie i oplata truda v promyshlennosti", No. 11, p. 41.

Gibalo, N.P. (2002). The problems of Russian economy institutionalization / Gibalo N.P., Skarzhinskaya M.I., Chekmarev V.V. I Monograph. Kostroma: KSU named after Nekrasov N.A., p. 45.

Gompers, S. (1912). Gompers Speaks for Labor. McClure's Magazine, February 1912, p. 376

Karelina, M.V. (2005). Regional trade unions in social dialogue // Sotsiologicheskie issledovaniya, No.3, pp.62-68.

Crouch, C. (1999). Social change in Western Europe (Oxford, Oxford University Press).

Morozova, L.S., Khavanova, N.V., Simonin, P.V., Litvinova, E.V. (2014) // Life Science Journal, Vol. 11, No. 4, p. 460.

Mikhalkina, E.V., Aleshin, V.A. (2013). Effective contract as an institute of social and labour relations in the area of higher education. Terra economicus, Vol. 11 No. 3, p. 91

Oksinoid, K.E. (1999). Social and labour relations as a type of social intercourse in economy in transition. Theses and report on the international conference [Electronic resource] / Oksinoid K.E. // collected works "Aktualnye problemy upravleniya-99", is.4, Moscow: State University of Management, p. 3.

Panov, V.V., Kotlyar, B.A., Rapoport, B.M. (1993). Responsible behaviour of parties - the base of social partnership // Sotsium i vlast, 2005. No.1, pp. 7-8.

Putmam, R. Making Democracy Work. N.Y., p. 216

Putman, R. (2000). Making democracy work: civic traditions in modern Italy // The library of the Moscow School of Political Studies.

Trade union space of modern Russia (2001) / Edited by Borisov V., Clark S. Moscow: ISITO, 331 p., p. 56, 137.

Sugden, R. Spontaneous Order //Journal of Economic Perspectives (1989), Vol. 3. No.4, p. 95.

Simonin P.V. (2014). Institutional features of social and labour relations development in higher educational institution // webzine "Naukovedenie", No. 3(22) [Electronic resource] Moscow: access mode: http://naukovedenie.ru/pdf/65EVN314.pdf. c.3-7.

Social partnership and employees' social protection. (2013). / Morozova L.S. et al. Moscow: Alfa-M: INFRA-M, p.104.

Labour law of Russia and EU states: collected works (2012). / Ed. by doctor of legal sciences, professor Skachkov G.S.; Russian Academy of Sciences; Institute of state and law. Moscow: RIOR: INFRA-M, p. 127.

Telicheva E.G. Labour market institutionalization рынка in Russia. (2005). / Telicheva E.G., Smirnov B.V. Khabarovsk: Pacific National University Press, $175 \mathrm{p}$.

Labour relations: state and development trends in Russia: collection of scientific papers (2013). / Edited by Yadov V.A. (editor in chief) [et al.]. Samara: Samara University Press, p.138.

Human resources management (2009). / Kibanov A.Y., Mitrofanova E.A., Esaulova I.A.; Ed. by Kibanov A.Ya. Moscow: INFRA-M, p.150.

Khavanova, N.V. (2007). Development of social partnership and sustainable business in the regions of Russia: monograph, State Educational Institution of Higher Professional Training Moscow State University of Services. Moscow, p.15, pp. 71-76

Hopkins P. (1985) Workers' Education: An international perspective (Milton Keynes, United Kingdom, Open University Press).

Sharunina, A.V. (2012). Is a Russian public-sector employee a looser? Analysis of intersectoral differences in remuneration: preprint WP3/2012/07 [Text] / Sharunina, A.V.; National research institute "Vysshaya shkola ekonomiki". Moscow: Vysshaya shkola ekonomiki. p. 30.

Schneider, F. (1997). The Shadow Economies of Western European Europe//Journal of the Institute of Economic Affairs, Vol.17, pp.4248. 
ISSN 2039-2117 (online) ISSN 2039-9340 (print)
Mediterranean Journal of Social Sciences MCSER Publishing, Rome-Italy
Vol 6 No $3 \mathrm{~S} 3$ May 2015 